\title{
Implementation of COVID-19 Preventive Measures in Primary and Secondary Schools Following Reopening of Schools in Autumn 2020; A Cross-Sectional Study of Parents' and Teachers' Experiences in England
}

Zahin Amin-Chowdhury ${ }^{1}$, Marta Bertran ${ }^{1}$, Meaghan Kall ${ }^{2}$, Georgina Ireland ${ }^{1}$, Felicity Aiano ${ }^{1}$, Annabel Powell ${ }^{1}$, Samuel E Jones ${ }^{1}$, Andrew Brent ${ }^{3}$, Bernadette Brent ${ }^{4}$, Frances Baawuah ${ }^{1}$, Ifeanychukwu Okike ${ }^{5}$, Joanne Beckmann ${ }^{6}$, Joanna Garstang ${ }^{7}$, Shazaad Ahmed ${ }^{8}$, Neisha Sundaram ${ }^{9}$, Chris Bonell ${ }^{10}$, Sinead Langan ${ }^{11}$, James Hargreaves ${ }^{12}$, Shamez N Ladhani ${ }^{1,13}$ Affiliations:

${ }^{1}$ Immunisation and Countermeasures Division, Public Health England, Colindale, London NW9 5EQ, UK

${ }^{2}$ National COVID-19 Epidemiology Cell, Public Health England, London, UK

${ }^{3}$ Nuffield Department of Medicine, University of Oxford, Oxford University Hospitals NHS

Foundation Trust, Oxford, UK

${ }^{4}$ Oxford University Hospitals NHS Foundation Trust, Oxford, UK

${ }^{5}$ Derbyshire Children's Hospital, University Hospitals of Derby and Burton NHS foundation Trust, Derby, UK

${ }^{6}$ Specialist Children \& Young People's Services, East London NHS Foundation Trust, London, UK

${ }^{7}$ Birmingham Community Healthcare NHS Trust \& University of Birmingham, Birmingham, UK

${ }^{8}$ Department of Virology, Manchester Foundation Trust, Manchester, UK

${ }^{9}$ Department of Global Health and Development, London School of Hygiene \& Tropical Medicine, London, UK

${ }^{10}$ Department of Non-communicable Disease Epidemiology, London School of Hygiene \& Tropical Medicine, London, UK

${ }^{11}$ Department of Public Health, Environments and Society, London School of Hygiene \& Tropical Medicine, London, UK

${ }^{12}$ London School of Hygiene \& Tropical Medicine, London, UK

${ }^{13}$ Paediatric Infectious Diseases Research Group (PIDRG), St. George's University of London, Cranmer Terrace, London SW17 ORE, UK.

Short title: Implementation of preventive measures in schools in England

Keywords: preventive measures, schools, COVID-19, SARS-CoV-2

Word count: 4,490 
Corresponding Author: Dr Shamez Ladhani, Immunisation and Countermeasures Division, Public Health England, 61 Colindale Avenue, London NW9 5EQ, UK. Email:

shamez.ladhani@phe.gov.uk

Alternate Corresponding Author: Zahin Amin-Chowdhury, Immunisation and

Countermeasures Division, Public Health England, 61 Colindale Avenue, London NW9 5EQ,

UK. Email: zahin.amin@phe.gov.uk

Author statement: ICMJE criteria for authorship was met by all authors.

\section{Patient and public involvement}

There was no patient or public involvement in the design of the study or the analysis. 


\section{Abstract \\ Objective}

The main objective was to assess implementation of and ease of implementation of control measures in schools as reported by staff and parents.

\section{Design}

Cross-sectional study.

\section{Setting}

Staff and parents/guardian participants in the 132 primary schools and 20 secondary schools participating in SKIDs and SKIDsPLUS surveillances.

\section{Main outcome measure}

Prevalence of control measures implemented in Autumn 2020, parental and staff perception of ease of implementation and acceptability of conducting school surveillance studies.

\section{Results}

In total, 56/152 (37\%) schools participating in Public Health England's sKIDs study of COVID in schools accepted the invitation to participate in the survey. By 28 December 2020, 1,953 parent and 986 staff respondents had completed the online questionnaire. While more than half the parents were positive about their children returning to school, roughly a third reported being a little anxious. $90 \%$ and $82 \%$ of primary and secondary school parents were either completely or partly reassured by the preventive measures implemented in their schools. Among staff, $80 \%$ of primary staff and $87 \%$ of secondary school staff felt that they were at higher risk of COVID-19 because of their profession; only $52 \%$ of primary school staff and $38 \%$ of secondary school staff reportedly felt safe. According to the teaching staff, most preventive measures were well-implemented apart from requiring 2-metre distancing between staff. For students, maintaining the 2-metre distance was reported to be particularly difficult. By extension, secondary schools also struggled to maintain small groups at all times or ensuring that the same staff were assigned to each student group (a problem also commonly reported by parents).

\section{Conclusions}

Variable implementation of infection control measures was reported by staff and parents. Whilst the majority were not worried about returning to school, some parents and staff, were concerned about returning to school and the risks posed to children, staff and household members. 


\section{Strengths and limitations of this study}

Strengths

- This study is one of the few to investigate school staff and parents' perceptions of the implementation of control measures implemented following the reopening of schools in England.

- The early establishment of COVID-19 surveillance in primary and secondary schools in the summer term 2020 provided a cohort to rapidly evaluate the experiences of parents and school staff during the autumn term before schools were required to close for the subsequent national lockdown.

Limitations

- As the questionnaire and information provided was available in English only, there is likely to be an under-representation of families for whom English was not their main language.

- Some school responses were only provided by one participant so may not necessarily be representative of the whole school.

- Although the surveillance included schools recruited nationally, a convenience sample was used and as such may not be representative of all primary and secondary schools in England. 
medRxiv preprint doi: https://doi.org/10.1101/2021.06.03.21258289; this version posted June 6, 2021. The copyright holder for this preprint (which was not certified by peer review) is the author/funder, who has granted medRxiv a license to display the preprint in perpetuity. It is made available under a CC-BY-NC-ND 4.0 International license .

\section{Background}

Children have been, comparatively less affected by coronavirus disease 2019 (COVID-19) caused by severe acute respiratory syndrome coronavirus 2 (SARS-CoV-2), representing only $1-3 \%$ of confirmed COVID-19 cases, with very few hospitalisations and deaths. ${ }^{2-4}$ Whether or not schools should remain open or closed remains a contentious topic for debate in the COVID-19 pandemic. $^{5}$

Early in the pandemic, the role of children in transmission of SARS-CoV-2 was still unclear and many countries implemented national lockdowns which included school closures. ${ }^{6}$ In the UK, children of key workers and vulnerable children, however, continued to attend school throughout the first lockdown. Subsequently, from 01 June 2020, some school years (nursery, reception, year 1 and year 6) returned to school, followed by some secondary school years (years 10 and 12) from 15 June 2020, although school attendance was not mandatory. ${ }^{7}$ The second half of the summer term was continued until 18 July 2020 before summer holidays began. During this period, strict physical distancing and infection control measures were implemented in schools, including limiting class sizes to small numbers, who remained in strict social bubbles that did not interact physically or social with other bubbles in school. ${ }^{8}$ The success of the summer half-term (where few cases and outbreaks of COVID19 were reported) contributed to the wider re-opening of all schools with full attendance in the autumn term, which started in September $2020 .^{9}$

The large number of students attending primary and secondary schools during the autumn term was likely to raise significant challenges for implementing and reinforcing physical distancing and infection control measures. In addition to the challenges of maintaining infection control measures in educational settings, community SARS-CoV-2 infection rates were higher at the start of the autumn term compared to the previous summer half-term. ${ }^{10}$ This in turn raised concerns about increased risk of SARS-CoV-2 introduction into education settings, via outbreaks that result in isolation of large class bubbles or potential closures if infection could not be controlled through current national guidelines and recommendations. ${ }^{11}$

To better understand the impact of SARS-CoV-2 in educational settings, Public Health England (PHE) has been conducting SARS-CoV-2 surveillance since the start of the pandemic in England which has included swabbing and serological sampling in selected primary and secondary schools. ${ }^{9}$ As part of this surveillance, we assessed the experiences and challenges of returning to school during the Autumn term by inviting the schools taking part in PHE school studies to participate in an online survey aimed at teaching staff and parents two months after the students returned to school in September 2020. 


\section{Methods}

\section{Schools surveillance}

As part of national surveillance, PHE initiated enhanced surveillance in 132 primary schools which were selected as previously described ${ }^{12}$ in five sites across England (East London, North and West London, Derby, Oxford and Manchester), during the summer half-term where staff and students were tested for SARS-CoV2 infection through weekly swabbing or blood sampling for SARS-CoV-2 antibodies at the beginning and end of the summer halfterm (sKIDs studies). From September 2020, surveillance was extended to include 20 secondary schools (sKIDsPLUS study). ${ }^{13}$

Study design

A cross-sectional survey was conducted among staff - including teachers, teaching assistants and senior leadership teams - and parents/guardians in the 132 primary schools and 20 secondary schools participating in SKIDs and sKIDsPLUS surveillance. PHE's studies. These schools were invited to take part in the online survey during the first week of November 2020, when schools returned from the half-term holidays. Schools expressing an interest in taking part were provided with an online link to forward to the teaching staff and all the parents in that school, irrespective of whether they were taking part in the sKIDs surveillance. The surveys were disseminated on 10 November 2020 and up to 5 email reminders were sent to encourage participants to complete the questionnaire until the last day of the survey on 28 December 2020.

Questionnaire design

Staff and parent questionnaires were adapted from those used during summer 2020 in a survey for headteachers and designed using Snap Professional 11 (SnapSurvey). ${ }^{14}$ Participants were provided with a list of preventive measures and were asked whether any of the measures were being implemented at their school as far as they were aware. Interventions were grouped into those related to students, staff or the classroom and school environment. Parents were asked to rate to what extent their child was able to follow these preventive measures. Similarly, staff were asked the ease of implementation of the control measures. The sKIDs and sKIDsPLUS studies were approved by PHE's ethics committee as a part of its responsibility to investigate SARS-CoV-2 infections among children in educational settings. Participants were informed that the survey was anonymised and voluntary, completion and return of questionnaire was taken as implied consent. 
Data analysis

Questionnaire responses from SnapSurvey were imported into Stata 15.1 (StataCorp, Tx). Data were cleaned and a descriptive analysis performed, stratified by parent/staff category and primary/secondary school. School profiles obtained from Department for Education data were used to compare school demographic characteristics including type of school, school size, percentage of students on free school meals and percentage of persistent absence in responding schools and non-responding schools. ${ }^{15}$ To report questions related to control measures at a school level, responses were weighted such that for schools with multiple responses, the contribution of each response summed to 1 in the weighting to compensate for overrepresentation of schools with more responses than others. Categorical variables are presented as proportions and compared using chi-squared or Fisher's Exact tests, where appropriate. Data that did not follow a normal distribution are described as median with interquartile ranges and compared using the Mann Whitney $U$ test.

\section{Results}

\section{Characteristics of parent and staff respondents}

In total, 152 schools participating in sKIDs and sKIDsPLUS across England were contacted, of which 56 (39\%) participated in the survey. By 28 December 2020, 1,953 parent and 986 staff respondents had completed the online questionnaire. Parents from 41/132 (31\%) primary schools with a mean response of 24 (range 1-109) and 15/19 (79\%) secondary schools (mean: 64; range (2-173) responded to the parent/guardian survey and staff from $56 / 132$ (42\%) primary schools (mean: 8; range (1-59) and 17/19 (90\%) secondary schools (mean: 30; range (10-66) responded to the staff survey. Response rates were higher in secondary schools which were larger but otherwise characteristics were broadly similar between responding and non-responding schools (Supplementary Table 1). Most primary school teachers $(81 \%)$ reported working in bubble sizes of $26-30(45 \%)$ or $>30(37 \%)$, while almost two-thirds of secondary school teachers $(63 \%)$ reported working in bubble sizes $>30$ or "other", which constituted the whole year group in most cases (data not shown).

\section{Parents}

Of those parents/guardians that responded, 999 (51\%) reported that their child attended primary school and 954 (49\%) attended secondary school. Approximately half of all 
medRxiv preprint doi: https://doi.org/10.1101/2021.06.03.21258289; this version posted June 6, 2021. The copyright holder for this preprint (which was not certified by peer review) is the author/funder, who has granted medRxiv a license to display the preprint in perpetuity. It is made available under a CC-BY-NC-ND 4.0 International license .

respondents $(1,029 / 1,953)$ reported that either they or their child's other parent/guardian was a key worker. Over a third of primary school parents $(345 / 999,35 \%)$ reported their child was eligible to receive free school meals, compared to only $13 \%(120 / 954)$ of secondary school parents (Supplementary Table 2). Only 45/1,953 (2\%) parents overall (6/999 (0.6\%) in primary and $39 / 954(4 \%)$ in secondary) reported their child had tested positive for SARSCoV-2 infection (data not shown).

Staff

In total, there were 471 (48\%) respondents from primary schools and 515 (52\%) respondents from secondary schools (Supplementary Table 2). Over half the primary school respondents were teachers $(268,57 \%)$ compared to $341(66 \%)$ of secondary school respondents. Conversely, there was a higher proportion of teaching assistants in primary (95, 19\%) compared with secondary $(147,31 \%)$ in secondary schools (Supplementary Table 2). Senior leadership team respondents including headteachers, deputy and assistant headteachers comprised $56(12 \%)$ primary and 51 (10\%) secondary staff respondents.

\section{Implementation of preventive measures at school}

\section{Student measures according to parents}

Parents from 93\% (51/56) reported that regular hand cleaning for students was the most frequently reported measure $(70,94 \%)$, and more frequently reported in primary (39/41, $96 \%)$ than in secondary schools $(13 / 15,84 \%)$ (Table 1). Other student measures that more frequently reported by primary than secondary school parents included respiratory hygiene (30/41, 73\% vs $13 / 15,63 \%)$, keeping students within the same small groups at all times $(28 / 41,69 \%$ vs $8 / 1555 \%)$ and ensuring the same teacher/staff member was assigned to each student group (29/41, 71\% vs 6/15, 38\%). Measures less commonly implemented in primary and secondary schools included daily/weekly rota for attending school was (11/41, $26 \%$ and $6 / 15,37 \%$, respectively) and were daily temperature checks $(2 / 41,4 \%$ and $2 / 15$, $10 \%$, respectively). In line with guidance, over three-quarters $(12 / 15,78 \%)$ of secondary parents reported that their child was required to wear a face covering while at school, compared to only $2 / 41(4 \%)$ in primary (Table 1$)$.

\section{Parents' perception of their child's compliance of preventive measures}

Among parents of primary school children, regular hand washing $(24 / 41,58 \%)$ and respiratory hygiene $(13 / 41,33 \%)$ were reported to be easiest to follow all the time (Figure 1). While wearing a face mask was not recommended in the guidelines for children under the 
medRxiv preprint doi: https://doi.org/10.1101/2021.06.03.21258289; this version posted June 6, 2021. The copyright holder for this preprint (which was not certified by peer review) is the author/funder, who has granted medRxiv a license to display the preprint in perpetuity. It is made available under a CC-BY-NC-ND 4.0 International license .

age of 11 years, $25 \%(10 / 41)$ of parents reported their child wore one on public transport always or most of the time. Compared to primary schools, parents of secondary school children reported higher compliance of all preventive measures in their children. Among parents of secondary school children, most reported that their child always wore a face mask/covering in public areas $(10 / 15,73 \%)$ or when on public transport $(9 / 15,60 \%)$. The most difficult measure to follow all the time among children of both primary $(4 / 15,30 \%)$ and secondary schools $(7 / 14,19 \%)$ was keeping a 2-metre distance from others when outside of the home, although most parents of primary $(22 / 41 ; 53 \%)$ and secondary school $(11 / 15$, $72 \%$ ) children reported that their child kept a 2-metre distance at least most of the time (Figure 2).

\section{Student measures according to staff}

Almost all staff in primary $(54 / 56,97 \%)$ and secondary schools $(16 / 17,96 \%)$ reported that the school ensured students with COVID-19 symptoms would be required to stay at home (Table 1). Similarly, regular hand washing was also reported to be widely implemented $(55 / 56,99 \%$ and $15 / 17,89 \%$, respectively). Some measures were rarely reported to be implemented, such as students attending school on daily/weekly rota $(8 / 56,15 \%$ and $3 / 17$, $17 \%$, respectively) and daily temperature checks for students $(4 / 56,7 \%$ and $1 / 17,8 \%$, respectively). Other measures reported at very different frequencies in primary and secondary schools included wearing face masks/coverings by students (16/17, 92\% and $2 / 56,4 \%$, respectively) as per national guidance, and ensuring the same staff are assigned to each student group $(37 / 56,67 \%$ and $3 / 17,17 \%$, respectively).

\section{Staff perception of students' compliance of preventive measures}

When asked how challenging staff found the implementation of student measures, the most challenging measure was requiring students to maintain 2-metre distancing in both primary $(37 \%)$ and secondary (58\%) schools. Where implemented, the easiest measures reported by staff were daily temperature checks for students (71\% and $88 \%$, respectively) and students attending school on a weekly/daily rota (70\% and $52 \%$, respectively). Regular hand cleaning was reported by staff to be easier to implement in primary (45\%) than in secondary (34\%) schools (data not presented.

\section{Preventive measures for staff}

The vast majority of primary schools $(54 / 56,97 \%)$ and secondary schools $(15 / 17,93 \%)$ as reported by staff had received guidance by the school on what to do if a student or staff has 
medRxiv preprint doi: https://doi.org/10.1101/2021.06.03.21258289; this version posted June 6, 2021. The copyright holder for this preprint (which was not certified by peer review) is the author/funder, who has granted medRxiv a license to display the preprint in perpetuity. It is made available under a CC-BY-NC-ND 4.0 International license .

COVID-19 symptoms. The majority of staff reported that their school required regular hand cleaning for staff ( $97 \%$ in primary/secondary) and requiring a 2-metre distance from others (83\%) (Table 2). Approximately half of primary (29/56, 51\%) and secondary (8/17, 47\%) reported that they had stopped all in-person staff meetings. Facemasks/coverings for staff members were reported to be implemented in $92 \%$ (16/17) secondary schools and $38 \%$ (22/56) primary schools (42\%). Other measures not commonly implemented by either primary or secondary schools included staff being advised to work from home if their job could be done from home (7-13\%) or if they lived in a household with an extremely clinically vulnerable individual (13-15\%). Less than half the primary (22/46, 39\%) and secondary $(7 / 17,41 \%)$ school staff reported that the school advised not to attend work or to work from home if they themselves were clinically vulnerable (Table 2).

Most $(16 / 17,92 \%)$ of secondary schools reported that they were advised to wear a face mask/covering outside classrooms, of which, $17 \%$ reported that they were required to wear them all the time. In comparison, 33\% primary school staff reported being required to wear a facemask/covering outside classrooms and only $6 \%$ reported to being required to wear them all the time. Of the remaining, $25 \%$ reported that they were given the option to wear a facemask/covering or not.

When asked how challenging it was to implement preventive measures for staff, the 2-metre distancing was the most challenging, with $27 \%$ of primary and $36 \%$ of secondary school staff reporting that it was 'very challenging' (Figure 2). In contrast, regular hand cleaning was the easiest to implement (79\% and $77 \%$, respectively). Most primary and secondary school staff reported that there were 'some challenges' to staff working from home if clinically vulnerable $(49 \%)$, if they were living with someone clinically vulnerable $(55 \%$ vs $58 \%)$ or if their work could be done from home ( $49 \%$ vs $61 \%$ ).

\section{School and the environment measures}

\section{Staff reporting of preventive measures in the school and classroom}

Fitting hand sanitisers at the school entrance, stopping large gatherings and staggering break times for different classes were among the most commonly reported measures by staff of both primary and secondary schools (>85\%). Some measures were more commonly reported to be more challenging by primary than secondary school staff, such as requiring 2metre distancing for parents dropping off or picking up children ( $87 \%$ vs $29 \%$, respectively) and staggering drop-off or collection times (92\% vs $72 \%$, respectively). Other measures 
medRxiv preprint doi: https://doi.org/10.1101/2021.06.03.21258289; this version posted June 6, 2021. The copyright holder for this preprint (which was not certified by peer review) is the author/funder, who has granted medRxiv a license to display the preprint in perpetuity. It is made available under a CC-BY-NC-ND 4.0 International license .

were not as commonly reported by staff, such as removing/disabling air flow hand driers from toilets (27-33\%) (Table 3$)$.

The majority of staff in primary and secondary schools reported that hand sanitisers were fitted in their classroom (40/56, $72 \%$ and $13 / 17,76 \%$, respectively) and that touch surfaces were frequently cleaned (50/56, 89\% and 15/17, 89\%, respectively) (Table 3). Other measures were more frequently reported by primary school staff than secondary school staff, such as removing soft furnishings and toys that are hard to clean (39/56, 69\% vs 4/17, $31 \%$, respectively), ensuring students were in the same classroom all day $(49 / 56,87 \%$ vs $7 / 17,39 \%$, respectively) and scheduling more lessons and activities outdoors (14/56, 25\% vs $1 / 17,3 \%$, respectively) (Table 3 ).

Fitting hand sanitisers in the classrooms, removing/disabling air flow hand driers from toilets and removing soft furnishing/toys that are hard to clean were some of the easiest measures to implement in both primary and secondary schools (>70\%). Maintaining space between seats and desks was reported by more than half the primary (52\%) and secondary school staff $(60 \%)$ to have 'some challenges'. Among primary school staff, the 2-metre distancing at drop-off/collection was reported to be the most challenging with the majority reporting that this measure had 'challenges' (52\%) or was 'very challenging' (31\%). Among secondary school staff, introducing a one-way system in corridors and staggering break times were reported to be most challenging with more than half reporting 'some challenges' (55\%) (data no presented.

\section{Discussion}

\section{Summary of key findings}

The early establishment of COVID-19 surveillance in primary and secondary schools provided a unique opportunity to rapidly evaluate the experiences of parents and teaching staff following the full reopening of all schools in England in September 2020. More than 150 schools taking part in sKIDs across England were invited to take part in the questionnaire survey and 58 agreed to forward the online questionnaire links to their staff and parents of students attending their schools. Reassuringly, more than half of parents were positive about their children returning to school, similar to findings of a similar US survey of parents. ${ }^{1}$ However, around a third of parents reported being a little anxious, while $13 \%$ and $16 \%$ of 
medRxiv preprint doi: https://doi.org/10.1101/2021.06.03.21258289; this version posted June 6, 2021. The copyright holder for this preprint (which was not certified by peer review) is the author/funder, who has granted medRxiv a license to display the preprint in perpetuity. It is made available under a CC-BY-NC-ND 4.0 International license .

primary and secondary school parents, respectively, reported being extremely anxious about their children returning to school. In general, when asked about preventive measures implemented in their schools, parents reported variable rates of implementation for their schools. In primary schools, staggering drop-off and collection times and stopping large gatherings of students such as assemblies were the only preventive measures reported by more than $75 \%$ of parents, and the latter was the only measure reaching this frequency in secondary schools. Overall, however, $90 \%$ and $82 \%$ of primary and secondary school parents were either completely or partly reassured by the preventive measures implemented in their schools.

Among staff, a significant finding of this survey was that $80 \%$ of primary staff and $87 \%$ of secondary school staff felt that they were at higher risk of COVID-19 because of their profession. Indeed, only $52 \%$ of primary school staff and $38 \%$ of secondary school staff felt safe at school despite the implementation of a wide range of social distancing and infection control measures. According to the teaching staff, preventive measures for staff were variably implemented, apart from regularly hand cleaning, maintaining a 2-metre distance between staff members and, for secondary school staff, wearing facemasks or face coverings while at school. In particular, most staff did not feel like they were given the option to work from home if possible, even if there was a clinical reason to do so. According to the teaching staff, most preventive measures were well-implemented apart from requiring 2metre distancing between staff.

For preventive measures involving students, too, maintaining the $2 \mathrm{~m}$ distance was found to be particularly difficult to implement for both primary and secondary schools, while secondary schools also struggled to maintain small groups at all times or ensuring that the same staff were assigned to each student group - a problem also commonly reported by parents. This was also reflected in teaching staff experiencing difficulties with maintaining space between seats and desks in both primary and secondary schools. Another problem faced particularly by secondary school teachers was ensuring that the students used the same classroom throughout the day and ensuring that the students do not carry materials between home and school. Other measures were implemented to a variable extent, except for parents dropping off or picking up secondary school students, which may be because most secondary school students are not picked up by their parents.

\section{Comparison with published literature}

It is difficult to compare the current experience of educational staff and parents of primary and secondary school students with other countries, each with different community SARS- 
medRxiv preprint doi: https://doi.org/10.1101/2021.06.03.21258289; this version posted June 6, 2021. The copyright holder for this preprint (which was not certified by peer review) is the author/funder, who has granted medRxiv a license to display the preprint in perpetuity. It is made available under a CC-BY-NC-ND 4.0 International license .

CoV-2 infection rates and implementation of local infection control measures to mitigate the risk of infection in their settings. We also used a standardised questionnaire to rapidly collect qualitative information from a large number of staff and students in school that were already participating in SARS-CoV-2 surveillance, which contrasts with other studies which mainly involved detailed interviews with a small number of staff and parents.

One cross-sectional survey study in England, using a convenience sample of 442 participants, measured parental perceptions of control measures implemented in their child's school in June. Their findings suggested that suboptimal practices were widespread, with only half of parents reporting hand-washing or hand gel dispensing facilities at school entrances and in classrooms and almost $40 \%$ reporting class sizes being larger than the recommended fifteen. ${ }^{16}$ With the full reopening of schools in the autumn term, limitation of class sizes into small distinct bubbles was no longer possible, especially for secondary schools, where classes are much larger than primary school classes.

In England, the experiences of the current autumn term when all the students returned to school is very different to the previous summer half-term, when only some primary and secondary school years, returned to school and with small class bubble sizes. At that time, detailed interviews with headteachers of the sKIDs schools identified different challenges in implementing infection control measures, including difficulties in prioritising teaching because of the additional requirement and practices, physical space constraints, staffing issues, finances, lack of adequate protective equipment and parent. The inability to maintain the 2-metre distance between the students and between students and staff, especially in primary schools, has been a consistent finding and not only challenging to implement but also considered incompatible with good teaching, especially in early-years classrooms. ${ }^{17}$

The autumn term is different to the previous summer half-term for a number of reasons. The number of students returning to school was much higher, increasing the challenges already encountered in maintaining physical distancing and infection control measures. At the same time, community infection rates were much higher between September and December 2020 than they were in June 2020, with increased numbers of cases in school-aged children, ${ }^{18}$ and outbreaks in primary and secondary schools. ${ }^{19}$ This had a large impact on the number of staff and student contacts required to self-isolate as part of the contact bubbles. Often whole classes and year groups had to self-isolate following a single confirmed case, and many staff and students had to self-isolate multiple times because they were contacts of different cases in their bubble. This was disruptive not only for the self-isolating students but also the remaining students because of the inconsistencies in school attendance and teaching staff. 
medRxiv preprint doi: https://doi.org/10.1101/2021.06.03.21258289; this version posted June 6, 2021. The copyright holder for this preprint (which was not certified by peer review) is the author/funder, who has granted medRxiv a license to display the preprint in perpetuity. It is made available under a CC-BY-NC-ND 4.0 International license .

\section{Strengths and limitations of this study}

The strength of this survey was the establishment of good relationships with primary and secondary school taking part in school surveillance studies which enabled a good response and the timely implementation of the survey during the autumn term before schools were required to close for the subsequent national lockdown. However, there are some limitations. We did not assess responses by demographics, such as ethnicity, or socio-economic status, which are very likely to influence questionnaire responses among staff and students, as has been reported elsewhere. ${ }^{1}$ Instead, we provided a summary of the demographics and results for all participants combined to ensure that the key messages reflect the group as a whole. Additionally, not all schools agreed to forward the questionnaire to their staff and parents, mainly because they too busy but this may have also introduced selection bias if those that felt less prepared were less willing to participate in the questionnaire survey, perhaps anxious about what this might reveal. While participating primary schools had a broad geographical spread across England, they are not representative of all primary and secondary schools in England. Primary schools participating in sKIDs were selected because they re-opened with at least 30 students in attendance during the summer halfterm. Similarly, secondary schools were identified for sKIDsPLUS because they were located in five regions where paediatric teams were available for taking blood samples for antibody testing from staff and students.

Of those who took part, it is likely that there was an under-representation of families for whom English was not their main language as well as those with limited access to digital platforms and the internet. Nonetheless, parents from 56 schools and staff from 73 schools agreed to take part and nearly 3,000 questionnaires were completed within 3 weeks, allowing us to rapidly analyse and report their experiences and concerns in a timely manner. Another limitation was that for some school responses were only provided by one participant so may not necessarily be representative of the whole school.

\section{Implications of findings}

The findings of this survey provide educationalists and policy-makers with real-world frontline data to help make more informed decisions to ensure that educational settings remain open throughout the pandemic. Education staff, including teachers, are working hard to follow national recommendations to help keep schools safely open during the COVID-19 pandemic, despite most of them considering themselves to be at increased risk of COVID-19 because of their profession and being concerned for their own health. Parents too expressed concern about schools reopening and, while most were not worried about the health of their children, they were worried about their children transmitting the virus to others, including vulnerable 
medRxiv preprint doi: https://doi.org/10.1101/2021.06.03.21258289; this version posted June 6, 2021. The copyright holder for this preprint (which was not certified by peer review) is the author/funder, who has granted medRxiv a license to display the preprint in perpetuity. It is made available under a CC-BY-NC-ND 4.0 International license .

household member. The impact of new COVID-19 variants with the potential for increased transmissibility will require careful monitoring when schools reopen during the Spring 2021 school term. ${ }^{20}$ As will the impact of mass testing using lateral flow devices that is currently being offered to staff and parents for school and home testing for SARS-CoV-2, a measure which may alleviate some of the concerns raised by parents staff and provide assurance. ${ }^{21}$

While most recommendations in the national guidance have been implemented to some extent in most schools, consistent concerns include difficulties in maintaining physical distancing within the school environment. This, along with difficulties of maintaining small bubble sizes following full reopening of schools, raises the question whether all staff and students should wear facemasks/covering in school, ${ }^{22}$ as has been implemented in other countries. ${ }^{23}$ Indeed, most parents appear to be supportive of children wearing masks in school. ${ }^{1}$ More generally, more studies are needed to assess the relative benefits of current infection control measures, including, but not restricted to, facemasks/coverings, so that future guidelines are more evidence-based. ${ }^{23,24}$

In particular, smaller class sizes, through blended in-school and home learning for example, would enable more effective implementation of the recommended infection control measures and provide additional reassurance for staff, parents and students. ${ }^{25}$ This would, however, only be possible if schools are provided with sufficient IT, computer hardware and internet support to allow the students to attend their classes online. ${ }^{26} \mathrm{We}$ also identified a need to improve communications between policy makers and education staff in schools. ${ }^{23}$ Many staff members commented on some unrealistic recommendations in the national guidance, such as maintaining physical distancing and seating arrangements within the class, whilst attempting to bring all the children back to school in the current autumn term. Providing individualised and pragmatic support for schools that are unable to implement some specific measures, including financial support where needed, would help improve relationships and ensure optimal prevention practices in educational settings. ${ }^{27}$ By the same token, improved communication with parents, either directly by policy makers or through schools, would provide additional reassurance about the safety of their children attending school. Consistent messaging and using social media to reach younger people would also help communicate public health messages to promote behaviours that reduce COVID-19 transmission. ${ }^{28,29}$

Overall, there is growing evidence the risk of infections and outbreaks in educational settings correlate strongly with community SARS-CoV-2 infections rates in adults. ${ }^{18,30,31}$ Interventions to reduce local community infection rates, including local and national lockdowns without school closures as was recently implemented in England, not only reduced SARS-CoV-2 infections in adults but also in school-aged children. On-going 
surveillance in educational settings, however, remains critical due to/as a result of the changing landscape of the pandemic.

\section{Conclusion}

Variable implementation of infection control measures and whilst the majority were not worried about returning to school, some parents and staff, were concerned about returning to school and the risk that posed to children, staff and household members. Following the closure of schools in January to March, the addition of regular mass testing to the suite of risk-reduction measures, some of these concerns may be alleviated. Continued monitoring of SARS-CoV-2 in schools, including the concerns for staff and parents, is required as society increasingly opens and the risks within schools alters. 


\section{TABLES}

Table 1 Student measures implemented as reported by parent/staff, respectively

\begin{tabular}{|c|c|c|c|c|}
\hline & Parent & & Staff & \\
\hline & $\begin{array}{l}\text { Primary } \\
\text { school } \\
\text { n (\%) } \\
\mathrm{N}=41\end{array}$ & $\begin{array}{l}\text { Secondary } \\
\text { school } \\
\text { n (\%) } \\
\mathrm{N}=15\end{array}$ & $\begin{array}{l}\text { Primary } \\
\text { school } \\
\text { n (\%) } \\
\mathrm{N}=56\end{array}$ & $\begin{array}{l}\text { Secondary } \\
\text { school } \\
\text { n (\%) } \\
\mathrm{N}=17\end{array}$ \\
\hline $\begin{array}{l}\text { Requiring maintenance of } \\
2 \mathrm{~m} \text { distance from others for } \\
\text { students }\end{array}$ & $12(30.3 \%)$ & 8 (51.4\%) & $13(23.8 \%)$ & 6 (32.8\%) \\
\hline $\begin{array}{l}\text { Requiring regular hand } \\
\text { cleaning for students }\end{array}$ & $39(96.0 \%)$ & $13(84.4 \%)$ & 55 (98.8\%) & 15 (89.2\%) \\
\hline $\begin{array}{l}\text { Ensuring students catch } \\
\text { cough or sneezes with } \\
\text { tissue or arm }\end{array}$ & $30(73.1 \%)$ & 9 (63.2\%) & $52(92.3 \%)$ & $11(65.5 \%)$ \\
\hline $\begin{array}{l}\text { Keeping students with the } \\
\text { same small groups at all } \\
\text { times each day }\end{array}$ & $28(68.8 \%)$ & 8 (55.0\%) & $43(76.6 \%)$ & $9(54.5 \%)$ \\
\hline $\begin{array}{l}\text { Ensuring that the same } \\
\text { teacher(s) and other staff } \\
\text { are assigned to each } \\
\text { student group }\end{array}$ & $29(71.2 \%)$ & $6(37.6 \%)$ & 37 (66.5\%) & 3 (14.9\%) \\
\hline $\begin{array}{l}\text { Students attending school } \\
\text { on a daily or weekly rota }\end{array}$ & $11(26.2 \%)$ & 6 (36.7\%) & $8(15.1 \%)$ & $3(16.8 \%)$ \\
\hline $\begin{array}{l}\text { Students required to wear } \\
\text { face masks or face } \\
\text { coverings while at school }\end{array}$ & $4(8.5 \%)$ & $12(78.4 \%)$ & $2(3.7 \%)$ & $16(92.1 \%)$ \\
\hline $\begin{array}{l}\text { Daily temperature checks for } \\
\text { students }\end{array}$ & $2(4.4 \%)$ & $2(10.0 \%)$ & $4(6.6 \%)$ & $1(7.7 \%)$ \\
\hline $\begin{array}{l}\text { Ensuring students who have } \\
\text { coronavirus symptoms, or } \\
\text { have someone at home who } \\
\text { does, stay home }\end{array}$ & - & - & 54 (97.1\%) & $16(96.1 \%)$ \\
\hline
\end{tabular}


Table 2 Preventive measures implemented at school for staff

\begin{tabular}{lll}
\hline & Staff & \\
\hline & $\begin{array}{l}\text { Primary school } \\
\mathbf{n}(\%) \\
\mathbf{N}=56\end{array}$ & $\begin{array}{l}\text { Secondary } \\
\text { school } \\
\mathbf{n}(\%) \\
\mathbf{n}=17\end{array}$ \\
\hline $\begin{array}{l}\text { Staff advised not to attend work or work from } \\
\text { home if clinically vulnerable }\end{array}$ & $22(39.3 \%)$ & $7(41.2 \%)$ \\
\hline $\begin{array}{l}\text { Staff advised to work from home if they live in a } \\
\text { household with someone who is extremely } \\
\text { clinically vulnerable }\end{array}$ & $7(13.1 \%)$ & $3(14.9 \%)$ \\
\hline $\begin{array}{l}\text { Staff advised to work from home if their job can be } \\
\text { done from home }\end{array}$ & $4(6.7 \%)$ & $2(13.2 \%)$ \\
\hline $\begin{array}{l}\text { Staff asked to wear facemasks or face coverings } \\
\text { while at school }\end{array}$ & $22(38.7 \%)$ & $16(92.4 \%)$ \\
\hline $\begin{array}{l}\text { Stopping in-person staff meetings } \\
\text { Requiring maintenance of 2m distance from others } \\
\text { for staff }\end{array}$ & $45(81.2 \%)$ & $14(84.3 \%)$ \\
\hline \begin{tabular}{l} 
Requiring regular hand cleaning for staff \\
\hline
\end{tabular} & $55(98.8 \%)$ & $16(92.0 \%)$ \\
\hline
\end{tabular}


Table 3 Preventive measures implemented at child's school (classroom and school environment)

\begin{tabular}{|c|c|c|c|c|c|}
\hline & $\begin{array}{l}\text { Primary } \\
\text { school } \\
\text { n (\%) } \\
\mathrm{N}=41\end{array}$ & $\begin{array}{l}\text { Secondary } \\
\text { school } \\
\text { n (\%) } \\
\mathrm{N}=15\end{array}$ & $\begin{array}{l}\text { Primary } \\
\text { school } \\
n(\%) \\
N=56\end{array}$ & $\begin{array}{l}\text { Secondary } \\
\text { school } \\
n(\%) \\
\mathrm{N}=17\end{array}$ & 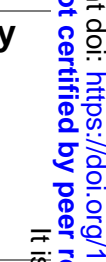 \\
\hline \multicolumn{5}{|l|}{ Classroom measures } & \\
\hline Fitting hand sanitisers in classrooms & $19(47.4 \%)$ & $9(60.7 \%)$ & $40(72.2 \%)$ & $13(76.4 \%)$ & \\
\hline Maintaining space between seats and desks & $22(52.9 \%)$ & $7(47.6 \%)$ & $28(50.8 \%)$ & $7(43.2 \%)$ & \\
\hline Removing non-essential objects from classrooms & - & - & $35(62.0 \%)$ & $7(41.2 \%)$ & 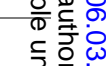 \\
\hline Removing soft furnishings and toys that are hard to clean & - & - & $39(69.0 \%)$ & $4(26.3 \%)$ & \\
\hline Cleaning frequently touched surfaces & - & - & $50(89.2 \%)$ & $15(89.2 \%)$ & ) \\
\hline Scheduling more lessons and activities outdoors & $13(31.3 \%)$ & $2(11.9 \%)$ & $14(25.4 \%)$ & $1(3.4 \%)$ & \\
\hline Ensuring students use the same classroom throughout the day & - & - & $49(87.7 \%)$ & $7(39.1 \%)$ & \\
\hline Ensuring students do not share equipment/learning materials in classrooms & - & - & $36(65.1 \%)$ & $12(70.4 \%)$ & 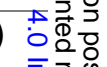 \\
\hline $\begin{array}{l}\text { Ensuring students do not carry equipment/learning materials between home and } \\
\text { school }\end{array}$ & $19(46.0 \%)$ & $3(20.0 \%)$ & $33(58.3 \%)$ & $2(13.7 \%)$ & \\
\hline \multicolumn{5}{|l|}{ School and the environment measures } & \\
\hline Introducing one-way systems in school corridors & $19(46.3 \%)$ & $9(63.1 \%)$ & $31(55.7 \%)$ & $11(63.8 \%)$ & 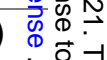 \\
\hline Fitting hand sanitisers at the school entrance & $17(42.5 \%)$ & $8(56.6 \%)$ & $50(89.3 \%)$ & $15(88.6 \%)$ & \\
\hline Removing / disabling air flow hand driers from toilets & - & - & $20(36.5 \%)$ & $4(23.4 \%)$ & \\
\hline Staggering drop-off and collection times & $31(74.7 \%)$ & $9(60.6 \%)$ & $50(89.0 \%)$ & $12(70.6 \%)$ & \\
\hline Staggering break times for different classes & - & - & $51(91.1 \%)$ & $14(85.2 \%)$ & \\
\hline
\end{tabular}




\begin{tabular}{|c|c|c|c|c|}
\hline Stopping large gatherings of students e.g. assemblies & $31(76.0 \%)$ & $10(68.8 \%)$ & $53(93.8 \%)$ & $15(88.5 \%)$ \\
\hline Stopping team sports & $14(35.4 \%)$ & $6(42.1 \%)$ & $30(53.9 \%)$ & $8(45.0 \%)$ \\
\hline Requiring $2 \mathrm{~m}$ distancing for parents dropping off or picking up children & $28(67.3 \%)$ & $4(27.9 \%)$ & $49(88.3 \%)$ & $4(23.4 \%)$ \\
\hline Allowing only one parent to accompany child to school & $22(53.7 \%)$ & $3(19.1 \%)$ & - & - \\
\hline Encouraging parents and children to not travel to school using public tra & $9(21.5 \%)$ & $5(30.2 \%)$ & & - \\
\hline
\end{tabular}




\section{FIGURES}

Figure 1 Child's compliance of preventive measures as reported by parents

Figure 2 Perceived ease of implementation of staff measures, by staff 


\section{Acknowledgements}

We would like to thank all the staff and parents who participated in the survey.

\section{Ethics approval}

The sKID and SKIDsPLUS studies received approval from the PHE Research and Ethics

Committee as part of PHE's responsibility to investigate risk and transmission of SARS-CoV2 among children in educational settings.

\section{Funding}

None

\section{Conflicts of interest}

None 


\section{References}

1. Gilbert LK ST, Szucs LE, et al. Racial and Ethnic Differences in Parental Attitudes and Concerns About School Reopening During the COVID-19 Pandemic - United States, July 2020. 2020

2. Zhu N, Zhang D, Wang W, Li X, Yang B, Song J, et al. A Novel Coronavirus from Patients with Pneumonia in China, 2019. N Engl J Med. 2020;382(8):727-33.

3. Swann OV, Holden KA, Turtle L, Pollock L, Fairfield CJ, Drake TM, et al. Clinical characteristics of children and young people admitted to hospital with covid-19 in United Kingdom: prospective multicentre observational cohort study. BMJ (Clinical research ed). 2020;370:m3249.

4. Ladhani SN, Amin-Chowdhury Z, Davies HG, Aiano F, Hayden I, Lacy J, et al. COVID-19 in children: analysis of the first pandemic peak in England. Archives of disease in childhood. 2020;105(12):1180-5.

5. Fantini MP, Reno C, Biserni GB, Savoia E, Lanari M. COVID-19 and the re-opening of schools: a policy maker's dilemma. Italian journal of pediatrics. 2020;46(1):79.

6. Li X, Xu W, Dozier M, He Y, Kirolos A, Theodoratou E. The role of children in transmission of SARS-CoV-2: A rapid review. Journal of global health. 2020;10(1):011101.

7. Actions for schools during the coronavirus outbreak. In: Education Do, editor. 2020.

8. Coronavirus (COVID-19): implementing protective measures in education and childcare settings. 2020.

9. Prospective active national surveillance of preschools and primary schools for SARS-CoV-2 infection and transmission in England, June 2020. 2020.

10. Mensah AA, Sinnathamby M, Zaidi A, Coughlan L, Simmons R, Ismail SA, et al. SARS-CoV-2 infections in children following the full re-opening of schools and the impact of national lockdown: Prospective, national observational cohort surveillance, July-December 2020, England. Journal of Infection. 2021.

11. Children's Task and Finish Group: Update on children, schools and transmission - 4 November 2020. (SAGE) CsTaFGTftSAGfE; 2020.

12. Ladhani Sea. Prospective Active National Surveillance of Preschools and Primary Schools for SARS-CoV-2 Infection and Transmission in England, June 2020. Lancet Regional Health - Europe. 2021.

13. COVID-19: paediatric surveillance. 2020.

14. Sundaram, Neisha; Bonell, Chris; Ladhani, SM; Langan, Sinéad M; Baawuah, F; Okike, I; Admad, S; Beckmann, J; Garstang, J; Brent, BE; Brent, AJ; Amin-Chowdhury, Zahin; Aiano, F; Hargreaves, James R; (2021) Implementation of health-promotion measures to prevent COVID-19: a national study of English primary schools in summer 2020. Health Education Research. ISSN 02681153 https://academic.oup.com/her (In Press)

15. Find and compare schools in England. 2019/20.

16. Smith LE, Woodland L, Amlôt R, Rubin A, Rubin GJ. A cross-sectional survey of parental perceptions of COVID-19 related hygiene measures within schools and adherence to social distancing in journeys to and from school. BMJ Paediatrics Open. 2020;4(1):e000825.

17. Guidance for schools: coronavirus (COVID-19). In: Education Do, editor. 2020.

18. Mensah AaS, Mary and Zaidi, Azad and Coughlan, Laura and Ismail, Sharif and Ramsay, Mary E. and Saliba, Vanessa and Ladhani, Shamez,. SARS-CoV-2 Infections in Children Following the ReOpening of Schools and the Impact of National Lockdown during Autumn 2020: Prospective, National Observational Cohort Surveillance, England (December 15, 2020). 2021.

19. Aiano FaM, Anna and McOwat, Kelsey and Obi, Chinelo and Vusirikala, Amoolya and Powell, Annabel and Flood, Jessica and Bosowski, Johanna and Letley, Louise and Jones, Samuel and AminChowdhury, Zahin and Lacy, Joanne and Hayden, lain and Ismail, Sharif A. and Ramsay, Mary E. and Ladhani, Shamez and Saliba, Vanessa. COVID-19 Outbreaks Following Full Reopening of Primary and Secondary Schools in England: Retrospective, Cross-Sectional National Surveillance. 2021. 
medRxiv preprint doi: https://doi.org/10.1101/2021.06.03.21258289; this version posted June 6, 2021. The copyright holder for this preprint

(which was not certified by peer review) is the author/funder, who has granted medRxiv a license to display the preprint in perpetuity.

It is made available under a CC-BY-NC-ND 4.0 International license .

20. Kirby T. New variant of SARS-CoV-2 in UK causes surge of COVID-19. The Lancet Respiratory Medicine.

21. Guidance: Rapid asymptomatic coronavirus (COVID-19) testing for staff in primary schools, school-based nurseries and maintained nursery schools, Updated 29 January 2021. In: Education Do, editor. 2021.

22. Spitzer M. Masked education? The benefits and burdens of wearing face masks in schools during the current Corona pandemic. Trends Neurosci Educ. 2020;20:100138-.

23. Esposito S, Cotugno N, Principi N. Comprehensive and safe school strategy during COVID-19 pandemic. Italian journal of pediatrics. 2021;47(1):6.

24. Patel S, Epalza Ibarrondo C, Toubiana J, Van der Linden D. Urgent need to develop evidencebased COVID-19 recommendations for primary schools. Archives of disease in childhood.

2020:archdischild-2020-321017.

25. Gandolfi A. Planning of school teaching during Covid-19. Physica D Nonlinear phenomena. 2021;415:132753.

26. Kroshus E, Hawrilenko M, Tandon PS, Christakis DA. Plans of US Parents Regarding School Attendance for Their Children in the Fall of 2020: A National Survey. JAMA pediatrics.

2020;174(11):1-10.

27. Carretero Gomez S, Napierala, J., Bessios, A., Mägi, E., Pugacewicz, A., Ranieri, M., Triquet, K., Lombaerts, K., Robledo Bottcher, N., Montanari, M. and Gonzalez Vazquez, I., . What did we learn from schooling practices during the COVID-19 lockdown, EUR 30559 EN, Publications Office of the European Union, Luxembourg. 2021.

28. Benham JL, Lang R, Kovacs Burns K, MacKean G, Léveillé T, McCormack B, et al. Attitudes, current behaviours and barriers to public health measures that reduce COVID-19 transmission: $A$ qualitative study to inform public health messaging. PloS one. 2021;16(2):e0246941.

29. Branquinho C, Kelly C, Arevalo LC, Santos A, Gaspar de Matos M. "Hey, we also have something to say": A qualitative study of Portuguese adolescents' and young people's experiences under COVID-19. J Community Psychol. 2020;48(8):2740-52.

30. Aspinall WP, Sparks RSJ, Cooke RM, Scarrow J. Quantifying threat from COVID-19 infection hazard in Primary Schools in England. medRxiv. 2020:2020.08.07.20170035.

31. Ismail SA, Saliba V, Lopez Bernal J, Ramsay ME, Ladhani SN. SARS-CoV-2 infection and transmission in educational settings: a prospective, cross-sectional analysis of infection clusters and outbreaks in England. The Lancet Infectious Diseases. 2021;21(3):344-53. 
medRxiv preprint doi: https://doi.org/10.1101/2021.06.03.21258289; this version posted June 6, 2021. The copyright holder for this preprint (which was not certified by peer review) is the author/funder, who has granted medRxiv a license to display the preprint in perpetuity.

It is made available under a CC-BY-NC-ND 4.0 International license.

\section{SUPPPLEMENT}

Supplementary Table 1: Overall characteristics of schools participating in parent and staff surveys

\begin{tabular}{|c|c|c|c|c|}
\hline & \multicolumn{2}{|c|}{ Parent } & \multicolumn{2}{|c|}{ Staff } \\
\hline & & $\mathrm{n}(\%)$ & & $n(\%)$ \\
\hline & Response & Non-response & Response & Non-response \\
\hline & $\mathrm{N}=56 / 152$ & $N=96 / 152$ & $\mathrm{~N}=76 / 152$ & $\mathrm{~N}=79 / 152$ \\
\hline \multicolumn{5}{|l|}{ Type of school } \\
\hline Academy/free school & $28(51.9 \%)$ & $45(49.5 \%)$ & $38(54.3 \%)$ & $35(46.7 \%)$ \\
\hline Community & $15(27.8 \%)$ & $28(30.8 \%)$ & $21(30.0 \%)$ & $22(29.3 \%)$ \\
\hline Foundation/Voluntary & $9(16.7 \%)$ & $14(15.4 \%)$ & $10(14.3 \%)$ & $13(17.3 \%)$ \\
\hline Independent & $0(0.0 \%)$ & $1(1.1 \%)$ & $0(0.0 \%)$ & $1(1.3 \%)$ \\
\hline Special school & $2(3.7 \%)$ & $3(3.3 \%)$ & $1(1.4 \%)$ & $4(5.3 \%)$ \\
\hline \multicolumn{5}{|l|}{ No of pupils on roll } \\
\hline$<200$ & $11(19.6 \%)$ & $20(21.3 \%)$ & $9(12.5 \%)$ & $22(28.2 \%)$ \\
\hline $200-499$ & $27(48.2 \%)$ & $56(59.6 \%)$ & $41(56.9 \%)$ & $42(53.8 \%)$ \\
\hline $500-799$ & $3(5.4 \%)$ & $12(12.8 \%)$ & $5(6.9 \%)$ & $10(12.8 \%)$ \\
\hline $800-999$ & $2(3.6 \%)$ & $4(4.3 \%)$ & $4(5.6 \%)$ & $2(2.6 \%)$ \\
\hline $1000+$ & $13(23.2 \%)$ & $2(2.1 \%)$ & $13(18.1 \%)$ & $2(2.6 \%)$ \\
\hline \multicolumn{5}{|l|}{$\%$ of pupils on FSM } \\
\hline$<5 \%$ & $9(16.1 \%)$ & $19(20.2 \%)$ & $11(15.3 \%)$ & $17(21.8 \%)$ \\
\hline $5-9 \%$ & $8(14.3 \%)$ & $6(6.4 \%)$ & $8(11.1 \%)$ & $6(7.7 \%)$ \\
\hline $10-19 \%$ & $15(26.8 \%)$ & $24(25.5 \%)$ & $19(26.4 \%)$ & $20(25.6 \%)$ \\
\hline $20-29 \%$ & $16(28.6 \%)$ & $19(20.2 \%)$ & $19(26.4 \%)$ & $16(20.5 \%)$ \\
\hline $30+\%$ & $8(14.3 \%)$ & $26(27.7 \%)$ & $15(20.8 \%)$ & $19(24.4 \%)$ \\
\hline \multicolumn{5}{|l|}{$\%$ of persistent absence } \\
\hline$<5 \%$ & $14(27.5 \%)$ & $19(22.4 \%)$ & $18(26.5 \%)$ & $15(22.1 \%)$ \\
\hline $5-9 \%$ & $14(27.5 \%)$ & $34(40.0 \%)$ & $21(30.9 \%)$ & $27(39.7 \%)$ \\
\hline $10+\%$ & $23(45.1 \%)$ & $32(37.6 \%)$ & $29(42.6 \%)$ & $26(38.2 \%)$ \\
\hline
\end{tabular}


medRxiv preprint doi: https://doi.org/10.1101/2021.06.03.21258289; this version posted June 6, 2021. The copyright holder for this preprint (which was not certified by peer review) is the author/funder, who has granted medRxiv a license to display the preprint in perpetuity. It is made available under a CC-BY-NC-ND 4.0 International license .

Supplementary Table 2: Parent and staff demographic and socioeconomic characteristics

\begin{tabular}{|c|c|c|c|c|}
\hline & \multicolumn{2}{|c|}{ Parent } & \multicolumn{2}{|c|}{ Staff } \\
\hline & $\begin{array}{l}\text { Primary } \\
\text { school }\end{array}$ & $\begin{array}{l}\text { Secondary } \\
\text { school }\end{array}$ & $\begin{array}{l}\text { Primary } \\
\text { school }\end{array}$ & $\begin{array}{l}\text { Secondary } \\
\text { school }\end{array}$ \\
\hline & n (\%) & n (\%) & n (\%) & n (\%) \\
\hline Number of respondents & $\mathrm{N}=999$ & $\mathrm{~N}=954$ & $\mathrm{~N}=471$ & $\mathrm{~N}=515$ \\
\hline Number of schools & $\mathrm{N}=41$ & $\mathrm{~N}=15$ & $\mathrm{~N}=56$ & $\mathrm{~N}=17$ \\
\hline \multicolumn{5}{|l|}{ Age group (years) } \\
\hline$\leq 25$ & $8(0.8 \%)$ & $1(0.1 \%)$ & $34(7.2 \%)$ & $35(6.8 \%)$ \\
\hline 26-35 & $250(25.0 \%)$ & $59(6.2 \%)$ & $127(27.0 \%)$ & $144(28.0 \%)$ \\
\hline $36-45$ & $513(51.4 \%)$ & 397 (41.6\%) & $110(23.4 \%)$ & $122(23.7 \%)$ \\
\hline $46-55$ & 207 (20.7\%) & $454(47.6 \%)$ & $141(29.9 \%)$ & $149(28.9 \%)$ \\
\hline$\geq 56$ & $21(2.1 \%)$ & $43(4.5 \%)$ & $59(12.5 \%)$ & $65(12.6 \%)$ \\
\hline \multicolumn{5}{|l|}{ Gender } \\
\hline Male & $114(11.4 \%)$ & $128(13.4 \%)$ & $68(14.4 \%)$ & $138(26.8 \%)$ \\
\hline Female & $885(88.6 \%)$ & $826(86.6 \%)$ & $402(85.4 \%)$ & $374(72.6 \%)$ \\
\hline Non-binary & $0(0.0 \%)$ & $0(0.0 \%)$ & $1(0.2 \%)$ & $3(0.6 \%)$ \\
\hline Ethnic group & $\mathrm{N}=982$ & $N=939$ & $\mathrm{~N}=456$ & $\mathrm{~N}=502$ \\
\hline White & $829(84.4 \%)$ & $726(77.3 \%)$ & $413(90.6 \%)$ & $429(85.5 \%)$ \\
\hline Asian & 72 (7.3\%) & $122(13.0 \%)$ & $19(4.2 \%)$ & $30(6.0 \%)$ \\
\hline Black & 35 (3.6\%) & 46 (4.9\%) & $9(2.0 \%)$ & 20 (4.0\%) \\
\hline Mixed & 25 (2.5\%) & $20(2.1 \%)$ & $11(2.4 \%)$ & $11(2.2 \%)$ \\
\hline Other & 21 (2.1\%) & 25 (2.7\%) & $4(0.9 \%)$ & $12(2.4 \%)$ \\
\hline $\begin{array}{l}\text { At least one parent } \\
\text { classified as key worker }\end{array}$ & $542(54.3 \%)$ & 487 (51.0\%) & & \\
\hline $\begin{array}{l}\text { Child eligible for free } \\
\text { school meals }\end{array}$ & 345 (34.5\%) & $120(12.6 \%)$ & & \\
\hline $\begin{array}{l}\text { Lives with anyone } \\
\text { considered to be high-risk }\end{array}$ & & & 85 (18.0\%) & $68(13.2 \%)$ \\
\hline $\begin{array}{l}\text { Number of children in } \\
\text { household }\end{array}$ & & & & \\
\hline
\end{tabular}

\section{1 to 2}

$\geq 3$

Role of staff in school 
medRxiv preprint doi: https://doi.org/10.1101/2021.06.03.21258289; this version posted June 6, 2021. The copyright holder for this preprint (which was not certified by peer review) is the author/funder, who has granted medRxiv a license to display the preprint in perpetuity.

\begin{abstract}
It is made available under a CC-BY-NC-ND 4.0 International license.
\end{abstract}

\begin{tabular}{|lll}
\hline Teacher & $268(56.9 \%)$ & $341(66.2 \%)$ \\
\hline Teaching assistant & $147(31.2 \%)$ & $95(19.2)$ \\
\hline Head/Deputy & $56(11.9 \%)$ & $51(10.3)$ \\
head/Assistant head & & \\
\hline
\end{tabular}


medRxiv preprint doi: https://doi.org/10.1101/2021.06.03.21258289; this version posted June 6, 2021. The copyright holder for this preprint (which was not certified by peer review) is the author/funder, who has granted medRxiv a license to display the preprint in perpetuity.

It is made available under a CC-BY-NC-ND 4.0 International license. 